\title{
The Effect of Select Personal Care Ingredients and Simple Formulations on the Attachment of Bacteria on Polystyrene
}

\author{
Kathleen C. Engelbrecht *, Stacy A. Mundschau, Vinod Chaudhary, Scott W. Wenzel and \\ David W. Koenig \\ Corporate Research and Engineering, Kimberly-Clark, Neenah, WI 54956, USA; \\ stacy.mundschau@kcc.com (S.A.M.); vinod.chaudhary@kcc.com (V.C.); scott.wenzel@kcc.com (S.W.W.); \\ dwkoenig@kcc.com (D.W.K.) \\ * Correspondence: kathleen.engelbrecht@kcc.com; Tel.: +1-920-721-2150
}

Received: 24 May 2018; Accepted: 6 July 2018; Published: 10 July 2018

\begin{abstract}
The human body is covered with bacteria that are required for health and wellbeing. Additionally, there are pathogenic bacteria that are unwanted. It is therefore important to understand how personal care ingredients interact with these bacteria. To help understand these interactions, a high-throughput assay was developed to study the effect of personal care ingredients on attachment. Seventeen personal care ingredients were assayed singly and in simple alcohol based formulations. Three of the ingredients decreased the attachment of both bacteria tested by $90 \%$ singly and in formulation. Personal care ingredients singly and in simple formulations can prevent the attachment of bacteria. Further research is needed to better understand how personal care ingredients affect bacterial attachment and how these effects can be used to create new hygiene products for consumers.
\end{abstract}

Keywords: microbiota; skin; formulation; adherence; surface

\section{Introduction}

The skin contains its own microflora of bacteria, viruses, and fungi. The resident microbes adapted to the skin constitute one of the many defenses humans have against pathogenic microbes [1,2]. These resident microbes vary between body sites with oily (face), moist (axilla), foot, and dry (palmar) sites having their own distinct microbiota [3]. Numerous activities have been reported to affect the bacteria that live on the skin including bathing/showering, and the use of soap and emollients [4]. However, non-discriminate removal of the resident skin microorganisms by surface active agents or annihilation using topical antimicrobials can destroy this beneficial ecology leaving room for transient pathogenic bacteria to be picked up [2]. These pathogenic bacteria can then cause disease or be spread to others. Preventing the attachment of pathogenic bacteria would provide considerable benefits to consumers by helping them maintain skin health and cleanliness. The effect of personal care ingredients on the attachment of bacteria has yet to be explored. The ability to selectively avoid pathogens with cosmetic formulations would provide an overall cleaning benefit, particularly for products such as hand sanitizers. A need exists to use a gentle nontoxic approach to prevent pathogenic bacteria from attaching to and thereby colonizing the skin.

Bacterial attachment begins with a non-specific, reversible attachment stage [5]. Non-specific attachment interactions include hydrophobic interactions, surface charge, loss of interfacial water, positioning of the bacteria to maximize contact with a surface, and topography of the cellular or abiotic surface [6]. The initial non-specific interactions that drive attachment of bacteria are the same for abiotic (polystyrene) and biotic (human skin) surfaces [7]. 
Considerable effort has been made in the areas of medical implants, biosensors, and marine coatings to identify ways to prevent the attachment of unwanted microorganisms. This research has yielded several chemical classes that have been successfully used to modify surfaces to prevent the attachment of bacteria including hydrophilic polymers, polyethylene glycol, zwitterionic compounds, and hydrophobic polymers [8]. These chemical classes can also be found the personal care realm. To determine if personal care ingredients could provide the same benefit of preventing bacteria from attaching to a surface, we screened select hydrophilic polymers, amphiphilic polymers, and silicone derivatives for their ability to prevent the attachment of bacteria $[9,10]$. A high throughput method was developed to quickly screen personal care ingredients and formulations for their effect on the initial non-specific attachment of bacteria to a polystyrene surface. Hand sanitizer formulations were chosen for this study due to their importance in providing a hygiene benefit to consumers. The purpose of this study was to determine the effect of select personal care ingredients and hand sanitizer formulations on the attachment of bacteria to a surface without regard to the antimicrobial effect of preservatives.

\section{Materials and Methods}

\subsection{Selection of Personal Care Ingredients}

Commonly used hydrophilic, amphiphilic, and silicone derivatives that are used as film-formers, rheology modifiers, and aesthetic modifiers in the personal care industry were selected for this study. The concentrations tested were based on vendor recommendations and commonly used ranges in personal care products.

\subsection{Single Ingredient Preparation}

All ingredients were prepared in 5\% $(v / v)$ glycerin (Vitusa Products, Berkeley Heights, NJ, USA)/water to the concentrations listed in Supplementary Materials, Table S1. All pH adjustments were performed using sodium hydroxide (Mallinckrodt, Phillipsburg, NJ, USA) or malic acid (Tate and Lyle, London, UK) for formulations containing methyl hydroxyethylcellulose to ensure neutralization (Supplementary Materials, Table S1). All ingredients were stored at $4{ }^{\circ} \mathrm{C}$ for up to $72 \mathrm{~h}$ prior to performing experiments.

\subsection{Simplified Alcohol Based Formulations}

All ingredients were added to a solution consisting of $60 \%(w / w)$ ethanol (Grain Processing, Muscatine, IA, USA) and 5\% $(w / w)$ glycerin (Vitusa Products, Berkeley Heights, NJ, USA). The remaining balance of each composition contained water to a total of $100 \% w / w$. All pH adjustments were performed as described above. All formulations were stored at $4{ }^{\circ} \mathrm{C}$ for up to $72 \mathrm{~h}$ prior to performing experiments.

\subsection{Determining Attachment of Bacteria to a Surface Using Plate Counts}

A modification of the high-throughput Minimum Biofilm Elimination Concentration (MBEC ${ }^{\mathrm{TM}}$ ) assay described by Ceri et al. (1999) was developed to test bacterial attachment [11]. The high-throughput assay, which uses Minimum Biofilm Elimination Concentration $\left(\mathrm{MBEC}^{\mathrm{TM}}\right)$ plates (Innovotech, Edmonton, AB, Canada), was performed at Innovotech, Edmonton, AB, Canada.

Using a positive displacement micropipette, $200 \mu \mathrm{L}$ of each ingredient to be tested was added to the wells of a 96-well untreated flat bottom microtiter plate (Corning Falcon ${ }^{\circledR}$, New York, NY, USA). An additional $200 \mu \mathrm{L}$ of each ingredient was added to a single well as a sterility control. Untreated polystyrene pegs were included as attachment controls. An $\mathrm{MBEC}^{\mathrm{TM}}$ lid was placed into the 96-well plate containing the test solutions. Each $\mathrm{MBEC}^{\mathrm{TM}}$ lid has 96 identical pegs, each with an average surface area of $108.9 \mathrm{~mm}^{2}$. The solutions and the polystyrene pegs were allowed to interact for $2 \mathrm{~h}$ at room temperature without shaking. The $\mathrm{MBEC}^{\mathrm{TM}}$ lid was then removed from the 96 -well plate and dried overnight. 
Bacteria (Escherichia coli ATCC 11229 and Staphylococcus aureus ATCC 6538) were grown overnight in tryptic soy broth (TSB, Becton, Dickinson and Company, Cockeysville, MD, USA) at $37^{\circ} \mathrm{C}$ with shaking, then subcultured under the same conditions for 16 to $18 \mathrm{~h}$. Bacteria were pelleted, washed once, and resuspended in PBS (Thermo Scientific ${ }^{\mathrm{TM}}$ Remel $^{\mathrm{TM}}$, Waltham, MA, USA). One hundred microliters of the appropriate bacteria were added to each well of a 96-well plate, excluding the sterility controls. The dried MBEC ${ }^{\mathrm{TM}}$ plate lid was placed into the 96-well plate containing the bacteria for $15 \mathrm{~min}$ at room temperature without shaking. After the $\mathrm{MBEC}^{\mathrm{TM}}$ plate lid was removed, loosely attached bacteria were removed by adding $200 \mu \mathrm{L}$ of a wash solution (1\% Tween-80 (Sigma-Aldrich, St. Louis, MO, USA)/phosphate buffered saline (PBS)) to each well of three separate 96-well plates. The inoculated MBEC plate lid was placed into the first wash plate for $15 \mathrm{~s}$, then removed. This was repeated twice more using a new wash plate each time (Supplementary Materials, Figure S1).

After the wash steps, the remaining attached bacteria were harvested by placing the inoculated MBEC $^{\mathrm{TM}}$ lid into a 96-well microtiter plate containing $200 \mu \mathrm{L}$ PBS in each well. The plate was sonicated using a $1 \mathrm{~min}$ on, $1 \mathrm{~min}$ off cycle for a total of $5 \mathrm{~min}$. An aliquot was removed from each well and bacteria were enumerated by performing 10-fold serial dilutions in PBS and plating on to tryptic soy agar plate (TSA, Becton, Dickinson and Company, Cockeysville, MD, USA). Attachment or nonattachment of bacterial cells was determined by calculating the Log colony forming units $(\mathrm{CFU}) / \mathrm{mL}$ of bacteria on the pegs in the presence of the ingredients and subtracting the Log CFU $/ \mathrm{mL}$ of the bacteria on pegs without ingredients. Statistical differences between the bacteria on untreated pegs to bacteria on treated pegs were determined using the student's $t$-test.

\subsection{Zone of Inhibition for Antimicrobial Activity}

A zone of inhibition assay was performed for all ingredients where a decrease in bacterial attachment to a polystyrene surface was observed. All ingredients were tested at the concentration listed in Supplementary Materials, Table S1. Bacteria (E. coli and S. aureus) were prepared as described for the surface bacterial attachment assay and diluted in PBS to approximately $10^{7} \mathrm{CFU} / \mathrm{mL}$. For each bacterial species, a sterile cotton-tipped swab (Copan, Murrieta, CA, USA) was dipped into the diluted bacteria and used to inoculate a bacterial lawn onto a TSA plate. The open end of a $1000 \mu \mathrm{L}$ pipette tip (Eppendorf, Hamburg, Germany) was used to remove 5 agar plugs from the inoculated TSA plate, creating $9 \mathrm{~mm}$ wells in the agar. Then, $100 \mu \mathrm{L}$ of each solution to be tested was added to one of the wells. For both bacterial species tested the following controls were used: $100 \mu \mathrm{L}$ chloramphenicol (Sigma-Aldrich, concentration tested $34 \mu \mathrm{g} / \mathrm{mL}$, diluted in PBS) was added to a well to demonstrate bacterial clearing and $100 \mu \mathrm{L}$ of PBS was used a negative control to demonstrate no bacterial clearing. The plates were incubated at $37^{\circ} \mathrm{C}$ for $16-18 \mathrm{~h}$ and observed to evaluate bacterial clearing.

\section{Results}

This study is the first to demonstrate that personal care ingredients affect the attachment of bacteria. A rapid and simple high throughput assay was developed to determine the effect of personal care ingredients on the attachment of bacteria to a surface. Representative Gram-negative (E. coli ATCC 11229) and Gram-positive (S. aureus ATCC 6538) bacteria were used to screen select ingredients used in personal care products. Bacterial growth controls demonstrated that a sufficient number of bacteria could be harvested from untreated polystyrene pegs, with an average of $4.7 \pm 0.3 \mathrm{Log}$ $\mathrm{CFU} / \mathrm{mL}$ of $E$. coli harvested after inoculation with an average of $9.1 \pm 0.2 \mathrm{CFU}$. Likewise, an average of $5.2 \pm 0.1 \mathrm{Log} C F U / \mathrm{mL}$ of $S$. aureus was harvested after inoculation with an average of $8.8 \pm 0.1 \mathrm{Log}$ $\mathrm{CFU} / \mathrm{mL}$. The assay was able to detect changes in the numbers of attached bacteria compared to the growth controls (Table 1). 
Table 1. Difference in viable counts $(\log \mathrm{CFU} / \mathrm{mL})$ of attached bacteria after exposure to personal care ingredients and formulations on pegs $(n=4)$ compared to untreated pegs ${ }^{1}$.

\begin{tabular}{|c|c|c|c|c|c|c|c|c|}
\hline \multirow{3}{*}{ INCI Name (Trade Name) } & \multicolumn{4}{|c|}{ Single Ingredient } & \multicolumn{4}{|c|}{ Alcohol Based Formulation } \\
\hline & \multicolumn{2}{|l|}{ E. coli } & \multicolumn{2}{|l|}{ S. aureus } & \multicolumn{2}{|l|}{ E. coli } & \multicolumn{2}{|l|}{ S. aureus } \\
\hline & $\begin{array}{l}\text { Change from } \\
\text { Growth Controls }\end{array}$ & $p$-Value & $\begin{array}{l}\text { Change from } \\
\text { Growth Controls }\end{array}$ & $p$-Value & $\begin{array}{l}\text { Change from } \\
\text { Growth Controls }\end{array}$ & $p$-Value & $\begin{array}{l}\text { Change from } \\
\text { Growth Controls }\end{array}$ & $p$-Value \\
\hline acrylates/steareth-20 methacrylate copolymer (Aculyn $\left.{ }^{\mathrm{TM}} 22\right)$ & -1.6 & 0.00 & -0.2 & 0.20 & -1.7 & 0.00 & -1.0 & 0.01 \\
\hline acrylates/vinyl neodecanoate crosspolymer (Aculyn ${ }^{\mathrm{TM}} 38$ ) & -0.7 & 0.00 & -0.2 & 0.10 & -0.6 & 0.01 & -0.6 & 0.06 \\
\hline ammonium acryloyldimethyltaurate/VP copolymer (Aristoflex ${ }^{\circledR}$ AVC) & -0.6 & 0.01 & -0.2 & 0.03 & -0.4 & 0.04 & -0.2 & 0.01 \\
\hline methylcellulose (Benecel $\left.^{\mathrm{TM}} \mathrm{A} 4 \mathrm{C}\right)$ & -1.4 & 0.00 & -1.1 & 0.00 & -1.8 & 0.00 & -1.6 & 0.00 \\
\hline hydroxypropyl methylcellulose (Benecel $\left.{ }^{\mathrm{TM}} \mathrm{E}-15\right)$ & -1.3 & 0.00 & -2.0 & 0.00 & -1.2 & 0.00 & -1.5 & 0.00 \\
\hline hydroxypropyl methylcellulose (Benecel ${ }^{\mathrm{TM}} \mathrm{K} 100 \mathrm{LV}$ ) & -1.0 & 0.00 & -0.1 & 0.25 & -0.9 & 0.00 & -0.0 & 0.35 \\
\hline cellulose gum (Aqualon ${ }^{\mathrm{TM}}$ Cellulose Gum) & -0.8 & 0.04 & -1.0 & 0.00 & -1.9 & 0.00 & -1.3 & 0.00 \\
\hline $\begin{array}{c}\text { acacia senegal gum }{ }^{2} \text { (TIC Prehydrated }{ }^{\circledR} \text { Gum Arabic } \\
\text { BEV-101 GR Powder) }\end{array}$ & -1.0 & 0.00 & -1.1 & 0.00 & -0.8 & 0.00 & -1.2 & 0.00 \\
\hline hydroxypropylcellulose (Klucel ${ }^{\mathrm{TM}}$ ECS) & -0.7 & 0.01 & -1.1 & 0.00 & -0.6 & 0.00 & -1.0 & 0.00 \\
\hline hydroxyethylcellulose (Natrosol ${ }^{\mathrm{TM}} 250 \mathrm{GR}$ ) & -0.7 & 0.00 & -0.9 & 0.00 & -0.5 & 0.08 & -0.2 & 0.04 \\
\hline hydroxyethylcellulose (Natrosol $^{\mathrm{TM}} 250 \mathrm{LR}$ ) & -1.0 & 0.03 & -1.1 & 0.00 & -1.0 & 0.00 & -1.0 & 0.00 \\
\hline $\begin{array}{l}\text { VP/dimethylaminoethylmethacrylate/polycarbamyl polyglycol ester } \\
\text { (Pecogel }{ }^{\circledR} \text { GC 310) }\end{array}$ & -0.8 & 0.00 & 0.1 & 0.26 & -1.1 & 0.00 & -1.2 & 0.00 \\
\hline 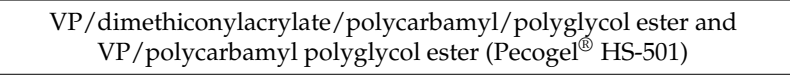 & -0.3 & 0.09 & -0.3 & 0.01 & -0.3 & 0.02 & -1.1 & 0.00 \\
\hline propylene glycol alginate (Protanal ${ }^{\circledR}$ Ester BV-3750) & -0.8 & 0.00 & -0.7 & 0.00 & -0.9 & 0.00 & -0.6 & 0.01 \\
\hline $\begin{array}{l}\text { glycerin; acrylates copolymer; VP/polycarbamyl polyglycol ester; } \\
\text { hydrolyzed sesame protein PG-propyl methylsilanediol (SesaFlash }{ }^{\mathrm{TM}} \text { ) }\end{array}$ & -1.1 & 0.00 & -0.9 & 0.00 & -0.4 & 0.03 & -1.0 & 0.00 \\
\hline $\begin{array}{c}\text { polyoxyethylene-polyoxypropylene block copolymer }{ }^{2} \\
\text { (UCON }\end{array}$ & -0.1 & 0.28 & -0.5 & 0.00 & -0.0 & 0.30 & -0.2 & 0.01 \\
\hline
\end{tabular}

${ }^{1}$ Untreated pegs were found to have $4.7 \pm 0.3 \mathrm{Log}$ CFU $/ \mathrm{mL}$ of E. coli and $5.2 \pm 0.1 \mathrm{Log}$ CFU $/ \mathrm{mL}$ S. aureus attached bacteria. ${ }^{2}$ INCI name not available, the manufacturer's chemical description is provided. 
A total of 17 single personal care ingredients were assayed to determine their effect on bacterial attachment to a surface (Table 1). A majority of the ingredients tested significantly $(p<0.05)$ decreased bacterial attachment to a polystyrene surface, with 15/17 ingredients significantly preventing attachment of E. coli and 13/17 ingredients significantly preventing attachment of $S$. aureus to the polystyrene surface. A reduction of bacteria by 1 Log represents a total decrease of bacteria by at least $90 \%$, which was achieved by eight ingredients for E. coli and six ingredients for S. aureus. Three ingredients (Benecel ${ }^{\mathrm{TM}} \mathrm{A} 4 \mathrm{C}$, Benecel ${ }^{\mathrm{TM}} \mathrm{E}-15$, and Natrosol ${ }^{\mathrm{TM}} 250 \mathrm{LR}$ ) decreased the attachment of both bacteria by at least $90 \%$. Not all compounds with the same INCI gave the same result. None of the ingredients tested had antimicrobial activity in the modified zone of inhibition assay.

To test if the decrease in attachment was also observed when the ingredients were used in formulations, simplified alcohol based formulations were developed and screened for their effect on attachment. No significant changes between the single ingredients and simple formulations were observed with regard to E. coli, however some changes were observed for the attachment of $S$. aureus. Three ingredients (Aculyn ${ }^{\mathrm{TM}}$ 22, Pecogel $^{\circledR}$ GC 310, and Pecogel ${ }^{\circledR}$ HS-501) demonstrated a larger decrease in attachment of $S$. aureus to the surface when combined with alcohol (Table 1).

\section{Discussion}

Personal care ingredients are used daily by people across the globe; however, outside of the antimicrobial effects, no studies have focused on the effects of personal care ingredients on bacterial attachment. This study shows that personal care ingredients and formulations affect the attachment of bacteria. None of the personal care ingredients tested had antimicrobial activity demonstrating that the observed decreases in attachment are a result of bacterial interaction with the ingredient. Importantly, use of personal care ingredients that decrease attachment of bacteria would provide additional benefits to consumers by allowing them to keep their skin clean.

A limitation of this work is that the attachment of bacteria was screened on polystyrene. However, it has some benefits, as it provides quick and efficient method to screen multiple personal care ingredients singly and in combination. Polystyrene has long been used to measure how well bacteria and fungi attach to surfaces [12-15]. Previous studies have shown that studies on bacteria and fungi with mutations in attachment have also been shown respond to polystyrene and skin surfaces in similar ways $[12,15]$.

Bacteria can be prevented from attaching by personal care ingredients and formulations. Escherichia coli was used as surrogate Gram-negative bacteria. Gram-negative bacteria are not usually isolated from human skin and are considered transient organisms that cause disease. Staphylococcus aureus was used a surrogate for Gram-positive bacteria. Gram-positive bacteria can be commensal or pathogenic (e.g., S. aureus) [16]. Preventing the attachment of Gram-negative transient bacteria and Gram-positive pathogens would aid in maintaining skin health.

Three of the personal care ingredients (Benecel ${ }^{\mathrm{TM}}$ A4C, Benecel ${ }^{\mathrm{TM}} \mathrm{E}-15$, and Natrosol ${ }^{\mathrm{TM}} 250 \mathrm{LR}$ ) by themselves and in alcohol based formulations decreased the attachment of both bacteria tested by $90 \%$ or greater $(\geq 1 \mathrm{Log}$, Table 1$)$. All three of the personal care ingredients that prevented bacterial attachment by over 1 Log were hydrophilic cellulosics. Previous work demonstrated that has that methylcellulose prevents bacterial attachment to rice straw [17]. However, not all cellulosics tested had the same activity, for example, Benecel ${ }^{\mathrm{TM}} \mathrm{K} 100 \mathrm{LV}$, while preventing the attachment of E. coli as both a single ingredient and in formulation, did not prevent the attachment of $S$. aureus (Table 1).

It is possible the hydrophilic cellulosics are preventing the attachment of bacteria by increasing the hydration layer of the polystyrene surface. Increasing the amount of water creates a physical barrier to attachment, thereby preventing the initial reversible attachment steps that drive bacterial attachment [18]. Numerous other factors including chain hydration, chain flexibility, and the interaction of the ingredient with the polystyrene may also be playing a role. However, determining a mechanism of action for personal care ingredients is difficult do to the proprietary nature of the ingredients. 
The ability to prevent bacteria from attaching would be particularly beneficial for formulations that are intended as leave-on compositions, such as hand sanitizers, moisturizers, and lotions. The resident bacteria of the hand are frequently exposed to both leave-on formulations and rinse-off formulations such as soaps. The importance of hands in the transfer of pathogenic bacteria to and from the self and the environment increases the need for leave-on products that provide additional cleanliness benefits. The bacterial community of the hand has been shown to fluctuate due to hygiene practices over short time periods (1-2 weeks) [3,19], however over the long term (up to 30 months) the community has been shown to be stable [3]. Further, differences in age, sex, and urban versus rural environment have been observed [20].

\section{Conclusions}

Overall, this study found that hydrophilic cellulosic personal care ingredients decreased the attachment of bacteria to a polystyrene surface. This work has meaningful impacts for the development of leave-on formulations. Leave-on formulations with the ability to prevent the attachment of bacteria can provide consumers with a cleanliness benefit. Further study is needed to identify additional personal care ingredients that affect attachment, determine the effect of personal care ingredients on eukaryotes (yeast) and viruses, possible mechanisms of action, performance of commercial hand sanitizing products, and how these effects can be used to create new product benefits for consumers. Future studies should be performed to study the effects of these ingredients in complex formulations and on the skin.

Supplementary Materials: The following are available online at http:/ /www.mdpi.com/2079-9284/5/3/42/s1, Figure S1: Schematic of the workflow, Table S1: List of ingredients and suppliers used in this study.

Author Contributions: All authors (K.C.E., S.A.M., V.C., S.W.W. and D.W.K.) conceived and designed the experiments; K.C.E., S.A.M. and V.C. performed the experiments; K.C.E. analyzed the data; and K.C.E wrote the paper.

Funding: This research received no external funding.

Acknowledgments: The authors would like to thank Debbie Ngai for her creation of the workflow schematic (Supplementary Materials, Figure S1).

Conflicts of Interest: All authors (K.C.E., S.A.M., V.C., S.W.W. and D.W.K.) are employed by Kimberly-Clark. This paper was prepared and written exclusively by the authors without review or comment by an outside entity.

\section{References}

1. Dethlefsen, L.; McFall-Ngai, M.; Relman, D.A. An ecological and evolutionary perspective on human-microbe mutualism and disease. Nature 2007, 449, 811-818. [CrossRef] [PubMed]

2. Cogen, A.L.; Nizet, V.; Gallo, R.L. Skin microbiota: A source of disease or defence? Br. J. Dermatol. 2008, 158, 442-455. [CrossRef] [PubMed]

3. Oh, J.; Byrd, A.L.; Park, M.; Kong, H.H.; Segre, J.A. Temporal stability of the human skin microbiome. Cell 2016, 165, 854-866. [CrossRef] [PubMed]

4. Kong, H.H.; Andersson, B.; Clavel, T.; Common, J.E.; Jackson, S.A.; Olson, N.D.; Segre, J.A.; Traidl-Hoffmann, C. Performing skin microbiome research: A method to the madness. J. Investig. Dermatol. 2017, 137, 561-568. [CrossRef] [PubMed]

5. Petrova, O.E.; Sauer, K. Sticky situations: Key components that control bacterial surface attachment. J. Bacteriol. 2012, 194, 2413-2425. [CrossRef] [PubMed]

6. Garrett, T.R.; Bhakoo, M.; Zhang, Z. Bacterial adhesion and biofilms on surfaces. Prog. Natl. Sci. 2008, 18, 1049-1056. [CrossRef]

7. Busscher, H.J.; Norde, W.; van der Mei, H.C. Specific molecular recognition and nonspecific contributions to bacterial interaction forces. Appl. Environ. Microbiol. 2008, 74, 2559-2564. [CrossRef] [PubMed]

8. Damodaran, V.B.; Murthy, N.S. Bio-inspired strategies for designing antifouling biomaterials. Biomater. Res. 2016, 20. [CrossRef] [PubMed] 
9. Rosenhahn, A.; Soren, S.; Kreuzer, H.J.; Grunze, M. The role of "inert" surface chemistry in marine biofouling prevention. Phys. Chem. Chem. Phys. 2010, 12, 4275-4286. [CrossRef] [PubMed]

10. Francolini, I.; Donelli, G.; Vuotto, C.; Baroncini, F.A.; Stoodley, P.; Taresco, V.; Martinelli, A.; D'Ilario, L.; Piozzi, A. Antifouling polyurethanes to fight device-related staphylococcal infections: Synthesis, characterization, and antibiofilm efficacy. Pathog. Dis. 2014, 70, 401-407. [CrossRef] [PubMed]

11. Ceri, H.; Olson, M.E.; Stremick, C.; Read, R.R.; Morck, D.; Buret, A. The Calgary Biofilm Device: New Technology for Rapid Determination of Antibiotic Susceptibilities of Bacterial Biofilms. J. Clin. Microbiol. 2018, 37, 1771-1776.

12. Henriksson, A.; Szewzyk, R.; Conway, P.L. Characteristics of the adhesive determinants of Lactobacillus fermentum 104. Appl. Environ. Microbiol. 1991, 57, 499-502. [PubMed]

13. Sonak, S.; Bhosle, N.B. A simple method to assess bacterial attachment to surfaces. Biofouling 2009. [CrossRef]

14. Gaddy, J.A.; Actis, L.A. Regulation of Acinetobacter baumannii biofilm formation. Future Microbiol. 2009, 4, 273-278. [CrossRef] [PubMed]

15. Li, F.; Palecek, S.P. EAP1, a Candida albicans gene involved in binding human epithelial cells. Eukaryot. Cell 2003, 2, 1266-1273. [CrossRef] [PubMed]

16. Grice, E.A.; Segre, J.A. The skin microbiome. Nat. Rev. Microbiol. 2011, 9, 244-253. [CrossRef] [PubMed]

17. Sung, H.G.; Kim, M.J.; Upadhaya, S.D.; Ha, J.K.; Lee, S.S. Effects of methylcellulose on cellulolytic bacteria attachment and rice straw degradation in the in vitro rumen fermentation. Asian-Australas. J. Anim. Sci. 2013, 26, 1276-1281. [CrossRef] [PubMed]

18. Chen, S.; Li, L.; Zhao, C.; Zheng, J. Surface hydration: Principles and applications toward low-fouling/nonfouling biomaterials. Polymer 2010, 51, 5283-5293. [CrossRef]

19. Zapka, C.; Leff, J.; Henley, J.; Tittl, J.; De Nardo, E.; Butler, M.; Griggs, R.; Fierer, N.; Edmonds-Wilson, S. Comparison of standard culture-based method to culture-independent method for evaluation of hygiene effects on the hand microbiome. mBio 2017, 8, e00093-17. [CrossRef] [PubMed]

20. Edmonds-Wilson, S.L.; Nurinova, N.I.; Zapka, C.A.; Fierer, N.; Wilson, M. Review of human hand microbiome research. J. Dermatol. Sci. 2015, 80, 3-12. [CrossRef] [PubMed] 